\title{
Identification and Characterization of Two Novel DSF-Controlled Virulence-Associated Genes Within the nodB-rhgB Locus of Xanthomonas oryzae pv. oryzicola Rs105
}

\author{
Zhiwei Song, Yancun Zhao, Xingyang Zhou, Guichun Wu, Yuqiang Zhang, Guoliang Qian, and Fengquan Liu
}

First, third, fourth, fifth, sixth, and seventh authors: College of Plant Protection, Nanjing Agricultural University, Nanjing 210095, China/Key Laboratory of Integrated Management of Crop Diseases and Pests (Nanjing Agricultural University), Ministry of Education, China; and second and seventh authors: Institute of Plant Protection, Jiangsu Academy of Agricultural Science, Nanjing 210014, P.R. China.

Accepted for publication 13 December 2014.

\begin{abstract}
Song, Z., Zhao, Y., Zhou, X., Wu, G., Zhang, Y., Qian, G., and Liu, F. 2015. Identification and characterization of two novel DSF-controlled virulenceassociated genes within the nodB-rhgB locus of Xanthomonas oryzae pv. oryzicola Rs105. Phytopathology 105:588-596.

Xanthomonas oryzae pv. oryzicola and X. oryzae pv. oryzae are two pathovars of $X$. oryzae that cause leaf streak and blight in rice, respectively. These two bacterial pathogens cause different disease symptoms by utilizing different infection sites on rice. Compared with $X$. oryzae pv. oryzae, the molecular virulence mechanism of $X$. oryzae pv. oryzicola remains largely unknown. Previously, we identified a unique diffusible signal factor (DSF)-controlled virulence-related gene $(h s h B)$ in $X$. oryzae pv. oryzicola Rs105 located in the nodB-rghB locus, which is absent in $X$. oryzae pv. oryzae $\mathrm{PXO} 99^{\mathrm{A}}$. In the present study, we identified two additional genes within this locus ( $h s h A$ and $h s h C$ ) that were unique to $X$. oryzae pv.

oryzicola Rs105 compared with X. oryzae pv. oryzae PXO99A, and we found that the transcription of these genes was regulated by DSF signaling in $X$. oryzae pv. oryzicola. The mutation of these genes impaired the virulence of the wild-type Rs 105 when using a low inoculation density of $X$. oryzae pv. oryzicola. In contrast to $h s h B$, the mutation of these genes did not have any visible effect on characterized virulence-related functions, including in vitro growth, extracellular polysaccharide production, extracellular protease activity, and antioxidative ability. However, we found that mutation of $h s h A$ or $h s h C$ significantly reduced the in planta growth ability and epiphytic survival level of $X$. oryzae pv. oryzicola cells, which was the probable mechanisms of involvement of these two genes in virulence. Collectively, our studies of $X$. oryzae pv. oryzicola have identified two novel DSF-controlled virulence-associated genes ( $h s h A$ and $h s h C$ ), which will add to our understanding of the regulatory mechanisms of conserved DSF virulence signaling in Xanthomonas species.
\end{abstract}

Xanthomonas is a large genus of gram-negative bacteria with a typical yellow appearance in colonies. This genus consists of a large number of phytopathogenic bacteria, which infect diverse crop plants of economic significance, including rice, citrus, banana, cabbage, and bean $(22,25)$. X. oryzae pv. oryzae and X. oryzae pv. oryzicola are two pathovars of $X$. oryzae. These two pathovars utilize distinct mechanisms to infect rice leaves and cause different symptoms. X. oryzae pv. oryzae is a vascular pathogen that enters rice leaves via the hydathodes causing bacterial blight, whereas $X$. oryzae pv. oryzicola penetrates rice leaves mainly through stomata or wound sites and colonizes intercellular spaces in the mesophyll, resulting in bacterial leaf streak (4). Compared with $X$. oryzae pv. oryzae, the molecular virulence mechanism of $X$. oryzae pv. oryzicola is poorly understood. Therefore, discovery of genetic determinants of virulence in $X$. oryzae pv. oryzicola will aid us to address this point.

Quorum sensing (QS) is a chemical signal-dependent and widely conserved cell-cell communication mechanism that coordinates various bacterial behaviors and gene expression patterns in a cell density-dependent manner (15). In most gram-negative bacteria, QS is mediated by the production and perception of $\mathrm{N}$-acyl homoserine lactones (AHLs) by two paired proteins belonging to the LuxI and LuxR families (11). However, Xanthomonas species

Corresponding authors: F. Liu; E-mail address: fqliu20011@sina.com and G. Qian; E-mail address: glqian@njau.edu.cn

*The $\boldsymbol{e}$-Xtra logo stands for "electronic extra" and indicates that nine supplementary figures and three supplementary tables are published online. do not produce AHLs; instead, they produce another type of QS signal, a diffusible signal factor (DSF). This signal was initially identified from $X$. campestris pv. campestris as cis-11-methyl-2dodecenoic acid (1,24). Recently, DSF and DSF-like molecules have been shown to be widely distributed in plant-associated bacteria, including Xanthomonas, Burkholderia, and Xylella $(3,6)$. The regulation of pathogenicity factor ( $r p f)$ gene cluster is required for DSF signaling in Xanthomonas $(2,14)$. The gene rpfF encodes a putative enoyl-CoA hydratase that catalyses the biosynthesis of the DSF molecule, while the two-component system RpfC-RpfG is responsible for the sensing and transduction of DSF signals $(1,13)$. Just like AHLs, DSF signals play important roles in virulence, cell motility, biofilm dispersal, the activity of extracellular enzymes, and extracellular polysaccharide (EPS) production in diverse bacteria $(5,8,10,14)$. Previously, we showed that the DSF cell-cell signaling of $X$. oryzae pv. oryzicola is required for virulence on host rice (27). A subsequent proteomic analysis of the wild-type strain Rs105 and a DSF-deficient mutant allowed us to identify several novel and DSFcontrolled virulence factors in $X$. oryzae pv. oryzicola; one of them is encoded by $h s h B$ (XOC_3772), located in the $\operatorname{nodB}$-rhgB locus of $X$. oryzae pv. oryzicola (26). This locus consists of 10 genes; four of them ( $h s h B$, hshA, XOC_3770, and XOC_3769) are genetically adjacent and predicted to be unique to the genome of $X$. oryzae pv. oryzicola Rs105 compared with X. oryzae pv. oryzae PXO99A (26). To be consistent with the names $h s h A$ and $h s h B$, we hereafter refer to $X O C_{3} 3770$ and $X O C_{\_} 3769$ as $h s h C$ and $h s h D$, respectively. With the exception of $h s h B$, the roles of the three remaining genes ( $h s h A$, $h s h C$, and $h s h D$ ) in virulence as well as their relationships with DSF signaling in $X$. oryzae pv. oryzicola are unknown.

Here, we provide experimental evidence showing that the homologs of $h s h A, h s h C$, and $h s h D$ of $X$. oryzae pv. oryzicola Rs 105 were lacking 
in $X$. oryzae pv. oryzae PXO99A. The transcriptions of $h s h A$ and $h s h C$, but not $h s h D$, were found to be regulated by the DSF system in $X$. oryzae pv. oryzicola. We further found that mutation of $h s h A, h s h C$, or double genes in $X$. oryzae pv. oryzicola caused a significant reduction of virulence on host rice when the inoculated cell population was low. Finally, we show that the decrease of $h s h A$ and $h s h C$ in virulence was associated with the reduced in planta cell colonization ability and the epiphytic survival level of the corresponding mutants. Collectively, our results provide two novel virulence-related genes ( $h s h A$ and $h s h C$ ) in $X$. oryzae pv. oryzicola, which is important for understanding the molecular mechanism of $X$. oryzae pv. oryzicola virulence.

\section{MATERIALS AND METHODS}

Bacterial strains, plasmids, and culture conditions. The bacterial strains and plasmids used in this work are listed in Supplementary Table 1. Escherichia coli strains were cultivated at $37^{\circ} \mathrm{C}$ in Luria-Bertani (LB) broth or LB agar plates. Unless specified otherwise, the wild-type strain Rs105 of X. oryzae pv. oryzicola and its derivative strains were grown at $28^{\circ} \mathrm{C}$ in nutrient broth (NB) medium (beef extract, $3 \mathrm{~g} /$ liter; yeast extract, $1 \mathrm{~g} / \mathrm{liter}$; polypeptone, $5 \mathrm{~g} /$ liter; and sucrose $10 \mathrm{~g} /$ liter) or on nutrient agar (NA). MMX (glucose at $5 \mathrm{~g} /$ liter, $\left[\mathrm{NH}_{4}\right]_{2} \mathrm{SO}_{4}$ at $2 \mathrm{~g} / \mathrm{liter}, \mathrm{MgSO}_{4}$. $7 \mathrm{H}_{2} \mathrm{O}$ at $0.2 \mathrm{~g} /$ liter, $\mathrm{K}_{2} \mathrm{HPO}_{4}$ at $4 \mathrm{~g} /$ liter, $\mathrm{KH}_{2} \mathrm{PO}_{4}$ at $6 \mathrm{~g} / \mathrm{liter}$, and trisodium citrate at $1 \mathrm{~g} /$ liter, $\mathrm{pH}$ 7.0) was used as the minimal medium. When required, antibiotics were added to the medium at the following final concentrations: ampicillin (Ap) at $100 \mu \mathrm{g} / \mathrm{ml}$ and kanamycin $(\mathrm{Km})$ at $50 \mu \mathrm{g} / \mathrm{ml}$ for E. coli; rifampicin (Rif) at $100 \mu \mathrm{g} / \mathrm{ml}$ and $\mathrm{Km}$ at $50 \mu \mathrm{g} / \mathrm{ml}$ for $X$. oryzae pv. oryzicola.

Generation of gene deletion mutants and complemented strains. The $X$. oryzae pv. oryzicola wild-type Rs 105 was used as the parental strain for generating in-frame deletion mutants via allelic homologous recombination, as described previously $(17,27)$. In brief, two flanking regions of each gene were generated by polymerase chain reaction (PCR) amplification by using different primer pairs. Two corresponding fragments of each gene were digested with appreciate restriction enzymes, and cloned into suicide vector $\mathrm{pK} 18 \mathrm{mobsacB}$ (28), creating individual recombinant vectors for each selected gene. These constructions were transformed into the wild-type strain Rs105 by electroporation, respectively. Transconjugants were selected on NA plates without sucrose and with Rif $(100 \mu \mathrm{g} / \mathrm{ml})$ and $\mathrm{Km}(50 \mu \mathrm{g} / \mathrm{ml})$. Positive colonies were plated on NA plates containing $10 \%$ (wt/vol) sucrose and Rif $(100 \mu \mathrm{g} / \mathrm{ml})$ to select for resolution of the construct by a second cross-over event. The resultant mutant containing the gene in-frame deletion was confirmed by PCR and Southern blotting (data not shown). For complementation, a series of expected DNA fragments containing each intact gene and predicted promoter were amplified by PCR method by using the primers listed in Supplementary Table 1 and cloned into the complemented-vector pUFR034 (7). The resultant constructs were transferred into the corresponding mutants by electroporation and confirmed by PCR, as described previously $(17,27)$.

Southern blot hybridization. Southern blot analysis was performed to verify the $h s h A, h s h C$, and $h s h D$ genes are unique in $X$. oryzae pv. oryzicola Rs105 compared with X. oryzae pv. oryzae PXO99A. For each of the three genes, two probes were used. Probe $\mathrm{P} 1$ is the internal fragment of each of the tested three genes. Probe $\mathrm{P} 2$ is the internal fragment of a conserved gene (grx, located in $n o d B-r g h B$ locus) both in $X$. oryzae pv. oryzicola Rs105 and $X$. oryzae pv. oryzae PXO99A. Three probe pairs, including P1$h s h D$ and $\mathrm{P} 2, \mathrm{P} 1-h s h C$ and $\mathrm{P} 2$, and $\mathrm{P} 1-h s h A$ and $\mathrm{P} 2$, were used to hybridize the genomic DNA of $X$. oryzae pv. oryzicola Rs105 and $X$. oryzae pv. oryzae PXO99A . In brief, a 533-bp internal fragment of $h s h D$ was amplified by primers $h s h D-F / h s h D-\mathrm{R}$ and labeled as the probe P1-hshD; a 519-bp internal fragment of $h s h C$ was amplified by primers $h s h C-\mathrm{F} / h s h C-\mathrm{R}$ and labeled as the probe
P1-hshC; a 710-bp internal fragment of $h s h A$ was amplified by primers $h s h A-\mathrm{F} / h s h A-\mathrm{R}$ and labeled as the probe $\mathrm{P} 1-h s h A$. Before hybridization, the genomic DNA of $X$. oryzae pv. oryzicola Rs105 and $X$. oryzae pv. oryzae PXO99A was digested by appreciated restriction enzymes (Fig. 1A). In brief, in the assay involving in $h s h D$, the genomic DNA of X. oryzae pv. oryzicola Rs105 was digested by BamHI and PstI. In the assay involved in $h s h C$ and $h s h A$, the genomic DNA of $X$. oryzae pv. oryzicola RS105 was digested by BamHI and $X b a \mathrm{I}$. In all experiment, the genomic DNA of X. oryzae pv. oryzae PXO99A was digested by BamHI and HindIII. All these digested genomic DNA samples were then separated by electrophoresis in a $1 \%$ agarose gel. The following steps of DNA hybridization were performed as described previously (18).

Pathogenicity test and determination of bacterial load in rice plants. Pathogenicity assays were performed in a glasshouse at 22 to $30^{\circ} \mathrm{C}$ as previously described $(17,27)$. In brief, X. oryzae pv. oryzicola strains were cultivated in NB medium at $28^{\circ} \mathrm{C}$ with appropriate antibiotics. Each $X$. oryzae pv. oryzicola strain was adjusted to a series of cell concentrations $\left(\mathrm{OD}_{600 \mathrm{~nm}}=0.5,0.05\right.$, 0.005 , and 0.0005 , respectively). Then, these cell suspensions were infiltrated into the leaves of 2-week-old rice seedlings (Shanyou-63, susceptible to the pathogen) by needless syringe. The water-soaking symptoms were measured at 10 days after inoculation. Ten leaves were inoculated for each $X$. oryzae pv. oryzicola strain in each treatment. The same experiment was performed three times.

Determination of bacterial load in infected rice plants was performed as described previously (26). In brief, colonization of each $X$. oryzae pv. oryzicola strain in rice leaf tissue was detected by homogenizing five inoculated leaves in $9 \mathrm{ml}$ of sterile water. The leaves were cut in 6-mm sections around the inoculation spots after 5 days of inoculation, while the same process was used to deal with leaves after 10 days of inoculation. Diluted homogenates were plated on NA plates supplemented with Rif (for the wild type and mutants). The number of bacterial colonies on these plates was counted after 2 days of incubation at $28^{\circ} \mathrm{C}$. Each diluted homogenate was plated on three plates, respectively. Three replicates for each treatment were used, and the experiment was performed three times.

Determination of bacterial epiphytic survival on rice leaf surface. The $X$. oryzae pv. oryzicola epiphytic survival assay was performed according to a recent report about $X$. axonopodis $\mathrm{pv}$. citrias (21), with minor modification. In brief, the cell population $\left(10^{8} \mathrm{CFU} / \mathrm{ml}\right)$ of the wild-type Rs105 and its derivatives were sprayed onto the leaves of 2-week-old rice seedlings (Shanyou-63, susceptible to the pathogen). After spraying, at least 10 rice leaves treated by each strain were collected at various time points $(0.5,4$, 12,20 , and $28 \mathrm{~h}$ ), respectively. Then, these rice leaves were cut into 6-mm sections, following by washing three times with sterile $\mathrm{ddH}_{2} \mathrm{O}$ to release the bacterial cells that were not adhered to leaf surface. Next, these pretreated rice leaf sections were homogenized, and diluted homogenates were plated on NA plates supplemented with Rif (for the wild type and mutants). The number of bacterial colonies on these plates was counted after 2 to 3 days of incubation at $28^{\circ} \mathrm{C}$. Each diluted homogenate was plated on three plates, respectively. Three replicates for each treatment were used, and the experiment was performed three times.

To statistically calculate the epiphytic survival level of each strain throughout the $28 \mathrm{~h}$, we used an AUPDC methodology (area under population dynamics curve) to do this analysis. The AUPDC analysis was performed as described previously (2), and it was calculated as follows:

$$
\mathrm{AUPDC}=\sum_{i=1}^{n}\left[\left(Y_{i+1}+Y_{i}\right) / 2\right]\left(X_{i+1}-X_{i}\right)
$$

where $Y_{i}$ is the $\log 10$ bacterial population at the $i$ th observation, $X_{i}$ is the time in hours at the $i$ th observation, and $n$ is the total number of observations. The AUPDC value of each strain was used to 
determine the significance between wild-type Rs105 and each tested mutant in the present study.

Growth rate of $X$. oryzae pv. oryzicola strains in MMX and NB. X. oryzae pv. oryzicola strains were grown in NB broth at $28^{\circ} \mathrm{C}$ with shaking at $200 \mathrm{rpm}$. Cells were collected at the early log phase $\left(\mathrm{OD}_{600 \mathrm{~nm}}=0.5\right)$ by centrifugation at $3,000 \times g$. Cell pellets were suspended in an equal volume of sterile $\mathrm{ddH}_{2} \mathrm{O}$. Then, $0.5 \mathrm{ml}$ of cell suspension was inoculated into $100 \mathrm{ml}$ of $\mathrm{NB}$ (a nutrient-rich broth). All inoculation broths were grown at $28^{\circ} \mathrm{C}$ with shaking at $200 \mathrm{rpm}$, and the $\mathrm{OD}_{600 \mathrm{~nm}}$ value was determined every $8 \mathrm{~h}$ until bacterial growth reached the stationary stage. The growth of $X$. oryzae pv. oryzicola strains in MMX (a minimal medium) was also measured. In brief, the initial inoculated bacterial concentration of tested strains was adjusted to $\mathrm{OD}_{600 \mathrm{~nm}}=1.0$. Then, a $300-\mu \mathrm{l}$ suspension was added into $30 \mathrm{ml}$ of $\mathrm{MMX}$ at $28^{\circ} \mathrm{C}$ with shaking at $200 \mathrm{rpm}$, and the $\mathrm{OD}_{600 \mathrm{~nm}}$ value was determined every $12 \mathrm{~h}$. Three replicates for each treatment were used, and the experiment was repeated three times.

Resistance to hydrogen peroxide. Experiments testing resistance to hydrogen peroxide $\left(\mathrm{H}_{2} \mathrm{O}_{2}\right)$ were carried out as described previously (26). In brief, the NA plates were made containing $\mathrm{H}_{2} \mathrm{O}_{2}$ concentrations of $0,0.1$, and $0.25 \mathrm{mM}$. X. oryzae pv. oryzicola strains were cultured to midlogarithmic phase $\left(\mathrm{OD}_{600 \mathrm{~nm}}=1.0\right)$ in NA medium. Then, threefold and ninefold dilutions were made. An aliquot of $5 \mu \mathrm{l}$ of initial culture and diluted cultures for each strain were spotted on NA plates and cultured for $36 \mathrm{~h}$ at $28^{\circ} \mathrm{C}$. Each strain was repeated three times. The same experiment was repeated at least three times.

Quantification of EPS production. EPS production of X. oryzae pv. oryzicola strains was measured with some modification as described previously $(23,26)$. Briefly, X. oryzae pv. oryzicola strains were grown in NB broth containing $4 \%$ glucose at $28^{\circ} \mathrm{C}$ with shaking at $200 \mathrm{rpm}$ for 5 days. EPS was precipitated from the culture supernatant with ethanol and dried at $80^{\circ} \mathrm{C}$ to constant weight. The difference between the two weights was used to estimate the production of EPS per milliliter of culture. Every experiment was repeated three times, and each treatment involved at least three replicates.

Determination of extracellular protease activity of $X$. oryzae pv. oryzicola strains. To measure the extracellular activity of protease, $2 \mu$ of bacterial culture $\left(\mathrm{OD}_{600 \mathrm{~nm}}=1.0\right)$ was spotted on NB agar plates containing $1 \%$ (wt/vol) skim milk powder. After incubation at $28^{\circ} \mathrm{C}$ for $36 \mathrm{~h}$, protease activity was measured and compared according to the hydrolytic zones around bacterial colony $(21,26)$. Each strain was repeated three times, and the same experiment was repeated at least three times.

Determination of cell swimming motility. Cell swimming motility assays were performed as described previously (19). In brief, cell cultures of each strain were normalized to an $\mathrm{OD}_{600 \mathrm{~nm}}$ of 0.5 , and $3 \mu \mathrm{l}$ of each prepared cultures was inoculated onto the surface of the motility plates (NA containing $0.3 \%$ agar). The motility halo was examined at 4 days after incubation at $28^{\circ} \mathrm{C}$. Three replicates for each treatment were used, and the experiment was performed three times.

DSF extraction and detection. DSF extraction from $X$. oryzae pv. oryzicola was performed as described previously $(16,26)$. Briefly, the $X$. oryzae pv. oryzicola wild-type Rs 105 was cultured to an $\mathrm{OD}_{600 \mathrm{~nm}}$ of 3.0 (stationary phase) in $200 \mathrm{ml}$ of NB broth at $28^{\circ} \mathrm{C}$ with shaking at $200 \mathrm{rpm}$. The culture was centrifuged at $8,000 \mathrm{rpm}$ for $20 \mathrm{~min}$ at $4^{\circ} \mathrm{C}$. Then, the supernatant was collected into a separating funnel, following by addition of $200 \mathrm{ml}$ of ethyl acetate for DSF signal extraction. The ethyl acetate phase was concentrated 100 -fold by evaporation, and was finally dissolved in $1 \mathrm{ml}$ of dimethyl sulfoxide. The assay for determination of the activity of DSF extraction was performed as described previously, using a DSF biosensor $(16,27)$. The validated DSF signal was used for further studies (see below).

Real-time PCR. Quantitative real-time reverse transcription PCR (qRT-PCR) was carried out by using SYBR Premix EX TagTM
II kit (TaKaRa) in an ABI PRISM 7500 Real-Time PCR System (Applied Biosystems). The 16S rRNA was used as an endogenous control. Primer sequences used in this assay were listed in Supplementary Table 2 . All the $X$. oryzae pv. oryzicola strain were grown in $\mathrm{NB}$ broth at $28^{\circ} \mathrm{C}$ with shaking at $200 \mathrm{rpm}$. For DSF supplement, $125 \mu \mathrm{l}$ of the validated DSF extraction was added into $25 \mathrm{ml}$ of the culture of the $r p f F$ mutant (the DSF-deficient mutant) (26). The cells of each strain, including those of the $r p f F$ mutant treated by DSF extraction, were collected at the midlogarithmic phase $\left(\mathrm{OD}_{600 \mathrm{~nm}}=1.0\right)$. These cells were used for RNA extraction using the RNAiso Plus reagent (TaKaRa) following the manufacturer's instructions. To remove genomic DNA, the eluted RNA samples were treated with RNase inhibitors and DNaseI (TaKaRa). RNA integrity was confirmed by electrophoresis using $1.2 \%$ agarose gels. Then $2 \mu \mathrm{g}$ of each RNA sample was used to synthesize cDNA with a cDNA synthesis kit (TaKaRa). The same experiment was performed three times. In this study, the transcriptional level of $h s h D, h s h C$, and $h s h A$ in wild-type Rs105 and its derivatives was assessed and compared, respectively. The gene $h s h B$ was used as a positive control; this gene was known to be regulated by DSF system at transcriptional level (26).

Data analysis. All analyses were conducted using SPSS 14.0 (SPSS Inc., Chicago, IL). The hypothesis test of percentages ( $t$ test, $P=0.05)$ was used to determine significant differences in the pathogenicity test, in planta colonization, epiphytic survival, and gene expressions.

\section{RESULTS}

Sequence analysis of the nodB-rhgB locus in Xanthomonas and related species. In the available genome of $X$. oryzae pv. oryzicola BLS256, the nodB-rhgB locus consists of 10 genes. This locus was highly conserved in $X$. oryzae pv. oryzicola Rs 105 (a Chinese isolate) used in this study (26). A BlastP search indicated that this locus was relatively conserved in Xanthomonas. As shown in Table 1, two or three of the genes (nodB, grx, and $\operatorname{rhg} B$ ) were highly conserved in Xanthomonas and related species such as Stenotrophomonas maltophilia R551-3 (a nosocomial pathogen) and Xylella fastidiosa 9a5c (the pathogen of Pierce's disease in grape). Sequence characterization of the genes within this locus showed that nodB encodes acetylxylan esterase; $g r x$ encodes a hypothetical protein; and $r h g B$ encodes rhamnogalacturonase $\mathrm{B}$ in the published genomes of Xanthomonas.

Similar to $h s h B$, three other genes ( $h s h A, h s h C$, and $h s h D)$ in this locus were not conserved in Xanthomonas and related species. The gene $h s h C$ encodes a hypothetical protein; $h s h A$ encodes an amidohydrolase family protein whose amidohydrolase family domains were similar to those of HshB (Supplementary Fig. 1); and $h s h D$ encodes a product belonging to the appr-1-p processing enzyme family. A detailed analysis revealed that different Xanthomonas species contained different numbers of these four genes at this locus. For example, X. campestris pv. vesicatoria 85-10 (the pathogen causing bacterial spot of pepper/tomato) contained homologs of these three genes ( $h s h A, h s h B$, and $h s h C$ ), and their organization in the genome was the same as that found in X. oryzae pv. oryzicola. X. campestris pv. campestris ATCC33913 (the pathogen causing black rot of crucifers) also harbored homologs of these three genes ( $h s h A, h s h B$, and $h s h C)$, while $X$. axonopodis pv. citri 306 (the pathogen causing citrus canker) had only one gene homolog $(h s h C)$. Interestingly, although $X$. oryzae pv. oryzae and $X$. oryzae pv. oryzicola, belonging to two pathovars of $X$. oryzae, shared a number of conserved proteins/genes, the homologs of three genes ( $h s h A, h s h B$, and $h s h C$ ) were all missing from the published genomes of $X$. oryzae pv. oryzae PXO99A, X. oryzae pv. oryzae MAFF311018, and $X$. oryzae pv. oryzae KACC10331, three model X. oryzae pv. oryzae strains. More interestingly, the $h s h D$ homolog was detected 
in the genomes of $X$. oryzae pv. oryzae MAFF311018 and $X$. oryzae pv. oryzae KACC10331, but not in X. oryzae pv. oryzae PXO99A genome.

Southern blotting verified the uniqueness of $h s h A, h s h C$, and $h s h D$ in the $X$. oryzae pv. oryzicola Rs105 genome compared with $X$. oryzae pv. oryzae PXO99A. As noted above, four genes ( $h s h A, h s h B, h s h C$, and $h s h D)$ in the nodB-rhgB locus of $X$. oryzae pv. oryzicola Rs 105 were predicted to be lacking in $X$. oryzae pv. oryzae PXO99A. We next performed Southern blotting using $X$. oryzae pv. oryzicola Rs105 and X. oryzae pv. oryzae PXO99A as subjects to verify this hypothesis experimentally. As shown in Figure 1, all three probe pairs detected bands $(\sim 7.5 \mathrm{~kb})$ in the $X$. oryzae pv. oryzae genome, which showed the presence of the conserved gene grx (indicated by a solid arrow). As expected, two clear bands were detected in the $X$. oryzae pv. oryzicola genome using each of the three probe pairs. Of these two bands, one suggested the presence of the conserved gene grx, while the other (indicated by a dashed arrow) indicated the uniqueness of each tested gene ( $h s h A, h s h C$, or $h s h D)$ in the $X$. oryzae pv. oryzicola Rs105 compared with $X$. oryzae pv. oryzae PXO99A. In details, as shown in Figure 1, by using the probe pairs, P1-hshA and P2, P1$h s h C$ and $\mathrm{P} 2, \mathrm{P} 1-h s h D$ and $\mathrm{P} 2$, the band corresponding to grx gene was detected as $\sim 7.0, \sim 7.0$, and $\sim 0.6 \mathrm{~kb}$ in $X$. oryzae pv. oryzicola Rs105, respectively; the band corresponding to $h s h A, h s h C$, and $h s h D$ gene was determined as $\sim 2.5, \sim 2.5$, and $\sim 4.5 \mathrm{~kb}$ in $X$. oryzae pv. oryzicola Rs105, respectively. The size of experimental hybridized band corresponding to each target gene was in line with our expected/predicted case in $X$. oryzae pv. oryzicola. The absence of $h s h B$ in $X$. oryzae pv. oryzae PXO99A was verified experimentally in a previous study (26). Together, these findings were consistent with those of the sequence analysis presented above. Collectively, our data showed that the genome of $X$. oryzae pv. oryzae PXO99A lacked homologs of the four genes ( $h s h A$, $h s h B, h s h C$, and $h s h D$ ) present at the $n o d B-r h g B$ locus in $X$. oryzae pv. oryzicola Rs105. Previously, we showed that $h s h B$ is involved in virulence and that its transcription is regulated by DSF signaling (26). This important finding prompted us to investigate the regulation and biological functions of the three remaining genes ( $h s h A, h s h C$, and $h s h D$ ) at the $\operatorname{nodB}-r h g B$ locus of $X$. oryzae pv. oryzicola Rs105 (see below).

Regulation of $h s h A$ and $h s h C$ transcription by the DSF system in $X$. oryzae pv. oryzicola. As reported previously, the gene $h s h B$ within the nodB-rhgB locus is modulated by DSF signaling at the transcriptional level in $X$. oryzae pv. oryzicola (26). This finding prompted us to test whether the transcription of $h s h A$, $h s h C$, or $h s h D$ is also modulated by the DSF system. For this purpose, corresponding qRT-PCR assays were performed. Using $h s h B$ as a positive control, we found a significant reduction in transcript abundance in a DSF-deficient mutant ( $\Delta r p f F)$ (Fig. 2), consistent with our previous findings (26). Under the same conditions, compared with the wild-type Rs105, mutation of rpfF caused a significant reduced $(\sim 2.3$-fold $)$ of the transcription of $h s h C$, and a dramatically reduced $(\sim 7.1$-fold $)$ of the transcription of $h s h A$ in $X$. oryzae pv. oryzicola (Fig. 2). These results suggest that the DSF system of $X$. oryzae pv. oryzicola regulated the transcription of $h s h A$ and $h s h C$. To verify this point, we performed additional experiments. The DSF signal from the wild-type Rs105 was extracted, and its activity was confirmed by the DSF biosensor (Supplementary Fig. 2). Then, the validated DSF extraction was supplemented into the $r p f F$ mutant to test whether the transcription of $h s h A$ or $h s h C$ could be restored to the wild-type level in X. oryzae pv. oryzicola. As expected, we found that the transcription of $h s h A$ or $h s h C$ in the $r p f F$ mutant was completely restored to wild-type level by adding of exogenous wild-type DSF (Fig. 2). Meanwhile, these two genes were also partially restored to the wild-type transcriptional level when the DSF biosynthetic gene (rpfF) was expressed in the background of the $r p f F$ mutant (Fig. 2). Collectively, these results indicate that the transcription of $h s h A$ or $h s h C$ was positively modulated by the DSF system in $X$. oryzae pv. oryzicola. Interestingly, disruption of the DSF system in $X$. oryzae pv. oryzicola did not alter the transcription of $h s h D$ under all tested conditions (Fig. 2).

Both $h s h A$ and $h s h C$ are required for the full virulence and in planta growth ability of $X$. oryzae pv. oryzicola. To examine the role of $h s h A, h s h C$, or $h s h D$ in the virulence of $X$. oryzae pv. oryzicola, we generated the corresponding in-frame deletion mutants of each gene. We then tested the virulence of the mutants by injecting bacterial cells into the rice leaves using the studied inoculated concentration $\left(\mathrm{OD}_{600 \mathrm{~nm}}=0.5\right)(18,26)$. Using this approach, we did not detect any visible difference in virulence between each mutant and the wild-type Rs105 (Supplementary Fig. $3 \mathrm{~A}$ and B). As noted above, the transcription of $h s h A$ or $h s h C$ was regulated by the DSF system (Fig. 2), suggesting that the functions of these genes are linked to the cell density of $X$. oryzae pv. oryzicola. To test this possibility, a series of X. oryzae pv. oryzicola cell concentrations $\left(\mathrm{OD}_{600 \mathrm{~nm}}=0.05,0.005\right.$, or 0.0005$)$ was applied through injection into rice leaves for additional virulence tests. At a concentration of $\mathrm{OD}_{600 \mathrm{~nm}}=0.05$ or 0.005 , all three mutants $(\Delta h s h A, \Delta h s h C$, and $\Delta h s h D)$ did not show visible difference in virulence in comparison with the wild-type Rs105, which was

TABLE 1. Conservation of each gene at the nodB-rhgB locus of Xanthomonas oryzae pv. oryzicola Rs105 in other Xanthomonas and related species ${ }^{\mathrm{a}}$

\begin{tabular}{|c|c|c|c|c|c|c|c|c|c|c|}
\hline \multirow{2}{*}{$\begin{array}{l}\text { X. oryzae pv. } \\
\text { oryzicola } \\
\text { RS105 }\end{array}$} & \multirow[b]{2}{*}{ Description } & \multirow{2}{*}{$\begin{array}{c}\text { X. oryzae } \\
\text { pv. oryzicola } \\
\text { BLS256 }\end{array}$} & \multicolumn{3}{|c|}{ X. oryzae pv. oryzae } & \multirow{2}{*}{$\begin{array}{l}X . \text { axonopodis } \\
\text { pv. citri } 306^{\mathrm{b}}\end{array}$} & \multirow{2}{*}{$\begin{array}{l}\text { X. campestris } \\
\text { pv. vesicatoria } \\
85-10^{\mathrm{b}}\end{array}$} & \multirow{2}{*}{$\begin{array}{l}\text { X. campestris } \\
\text { pv. campestris } \\
\text { ATCC } 33913^{\mathrm{b}}\end{array}$} & \multirow{2}{*}{$\begin{array}{c}\text { Stenotrophomonas } \\
\text { maltophilia } \\
\text { R551-3 }\end{array}$} & \multirow{2}{*}{$\begin{array}{c}\text { Xylella } \\
\text { fastidiosa } \\
\text { 9a5c }\end{array}$} \\
\hline & & & PXO99 ${ }^{\mathrm{A}}$ & MAFF311018 & KACC10331 & & & & & \\
\hline $\operatorname{nod} B$ & Acetylxylan esterase & $\begin{array}{l}\text { XOC_3765 } \\
(100 \%, 0.0)\end{array}$ & $\begin{array}{l}\text { PXO_02423 } \\
(98 \%, 5 \mathrm{e}-178)\end{array}$ & $\begin{array}{l}\text { XOO_0989 } \\
(98 \%, 1 \mathrm{e}-179)\end{array}$ & $\begin{array}{l}\text { XOO1091 } \\
(98 \% 2 \mathrm{e}-179)\end{array}$ & $\begin{array}{l}\text { XAC3499 } \\
(94 \%, 1 \mathrm{e}-170)\end{array}$ & $\begin{array}{l}\text { XCV3625 } \\
(96 \%, 8 \mathrm{e}-175)\end{array}$ & $\begin{array}{l}\text { XCC3367 } \\
(84 \%, 3 \mathrm{e}-151)\end{array}$ & $\begin{array}{l}\text { Smal_3369 } \\
\quad(59 \%, 3 \mathrm{e}-97)\end{array}$ & $\begin{array}{l}\text { XF2395 } \\
\quad(62 \%, 8 \mathrm{e}-107)\end{array}$ \\
\hline$g r x$ & Hypothetical protein & $\begin{array}{l}\text { XOC_3766 } \\
(100 \%, 0.0)\end{array}$ & $\begin{array}{r}\text { PXO_02424 } \\
(98 \%, 0.0)\end{array}$ & $\begin{array}{l}\text { XOO_0988 } \\
(98 \%, 0.0)\end{array}$ & $\begin{array}{l}\text { XOO_1090 } \\
(98 \%, 0.0)\end{array}$ & $\begin{array}{l}\text { XAC } 3500 \\
(97 \%, 0.0)\end{array}$ & $\begin{array}{l}\text { XCV3626 } \\
(97 \%, 0.0)\end{array}$ & $\begin{array}{l}\text { XCC } 3368 \\
(94 \%, 0.0)\end{array}$ & $\begin{array}{l}\text { Smal_3370 } \\
\quad(80 \%, 0.0)\end{array}$ & $\begin{array}{l}\text { XF2394 } \\
\quad(76 \%, 1 \mathrm{e}-172)\end{array}$ \\
\hline- & Hypothetical protein & $\begin{array}{l}\text { XOC_3767 } \\
(100 \%, 0.0)\end{array}$ & $\mathrm{N}$ & $\begin{array}{l}\text { XOO_0987 } \\
(77 \% \text { le-27) }\end{array}$ & $\mathrm{N}$ & $\mathrm{N}$ & $\mathrm{N}$ & $\mathrm{N}$ & $\mathrm{N}$ & $\mathrm{N}$ \\
\hline- & Hypothetical protein & $\begin{array}{l}\text { XOC_3768 } \\
(100 \%, 0.0)\end{array}$ & $\mathrm{N}$ & $\begin{array}{l}\text { XOO_0985 } \\
(96 \% 2 \mathrm{e}-42)\end{array}$ & $\mathrm{N}$ & $\mathrm{N}$ & $\mathrm{N}$ & $\mathrm{N}$ & $\mathrm{N}$ & $\mathrm{N}$ \\
\hline$h \operatorname{sh} D$ & $\begin{array}{l}\text { Appr-1-p processing } \\
\text { enzyme family }\end{array}$ & $\begin{array}{l}\text { XOC_3769 } \\
(100 \%, 0.0)\end{array}$ & $\mathrm{N}$ & $\begin{array}{l}\text { XOO_0982 } \\
(98 \%, 0.0)\end{array}$ & $\begin{array}{l}\text { XOO_1084 } \\
(99 \%, 0.0)\end{array}$ & $\mathrm{N}$ & $\mathrm{N}$ & $\mathrm{N}$ & $\mathrm{N}$ & $\mathrm{N}$ \\
\hline$h \operatorname{shC}$ & Hypothetical protein & $\begin{array}{l}\text { XOC_3770 } \\
(100 \%, 0.0)\end{array}$ & $\mathrm{N}$ & $\mathrm{N}$ & $\mathrm{N}$ & $\begin{array}{l}\text { XAC3502 } \\
(98 \%, 4 \mathrm{e}-125)\end{array}$ & $\begin{array}{l}\text { XCV3628 } \\
(96 \%, 1 \mathrm{e}-122)\end{array}$ & $\begin{array}{l}\text { XCC3370 } \\
(88 \%, 6 \mathrm{e}-106)\end{array}$ & $\begin{array}{l}\text { Smal_3371 } \\
\quad(56 \%, 9 \mathrm{e}-61)\end{array}$ & $\mathrm{N}$ \\
\hline$h s h A$ & $\begin{array}{l}\text { Amidohydrolase } \\
\text { family protein }\end{array}$ & $\begin{array}{l}\text { XOC_3771 } \\
(100 \%, 0.0)\end{array}$ & $\mathrm{N}$ & $\mathrm{N}$ & $\mathrm{N}$ & $\mathrm{N}$ & $\begin{array}{l}\text { XCV3629 } \\
(97 \%, 0.0)\end{array}$ & $\begin{array}{l}\text { XCC } 3371 \\
(93 \%, 0.0)\end{array}$ & $\begin{array}{l}\text { Smal_3373 } \\
(76 \%, 0.0)\end{array}$ & $\mathrm{N}$ \\
\hline$h s h B$ & Hypothetical protein & $\begin{array}{l}\text { XOC_3772 } \\
(100 \%, 0.0)\end{array}$ & $\mathrm{N}$ & $\mathrm{N}$ & $\mathrm{N}$ & $\mathrm{N}$ & $\begin{array}{l}\text { XCV3630 } \\
(94 \%, 0.0)\end{array}$ & $\begin{array}{l}\text { XCC3372 } \\
(89 \%, 0.0)\end{array}$ & $\begin{array}{l}\text { Smal_3374 } \\
(73 \%, 0.0)\end{array}$ & $\mathrm{N}$ \\
\hline- & Hypothetical protein & $\begin{array}{l}\text { XOC_3773 } \\
(100 \%, 0.0)\end{array}$ & $\begin{array}{l}\text { PXO_02429 } \\
\quad(95 \%, 6 \mathrm{e}-32)\end{array}$ & $\begin{array}{l}\text { XOO_0980 } \\
(95 \%, 3 \mathrm{e}-33)\end{array}$ & $\begin{array}{l}\text { XOO_1079 } \\
(95 \%, 3 \mathrm{e}-33)\end{array}$ & $\mathrm{N}$ & $\begin{array}{l}\text { XCV3631 } \\
\quad(81 \%, 1 \mathrm{e}-50)\end{array}$ & $\begin{array}{l}\text { XCC } 3376 \\
(73 \%, 7 \mathrm{e}-44)\end{array}$ & $\mathrm{N}$ & $\mathrm{N}$ \\
\hline $\operatorname{rhg} B$ & Rhamnogalacturonase B & $\begin{array}{l}\text { XOC_3774 } \\
(100 \%, 0.0)\end{array}$ & $\begin{array}{l}\text { PXO_02430 } \\
(98 \%, 0.0)\end{array}$ & $\begin{array}{l}\text { XOO_0978 } \\
(98 \%, 0.0)\end{array}$ & $\begin{array}{l}\text { XOO_1078 } \\
(98 \%, 0.0)\end{array}$ & $\begin{array}{l}\text { XAC3505 } \\
(87 \%, 0.0)\end{array}$ & $\begin{array}{l}\text { XCV3632 } \\
(86 \%, 0.0)\end{array}$ & $\begin{array}{l}\text { XCC } 3377 \\
(80 \%, 2 \mathrm{e}-123)\end{array}$ & $\mathrm{N}$ & $\mathrm{N}$ \\
\hline
\end{tabular}

${ }^{a}$ Parentheses indicate percent amino acid identity (left number) and E-value (right number). N, no homologs gene was identified. -, not named.

b Data were consistent with our previous study (26), and used here as a control. 
A

Xoc (Rs105)
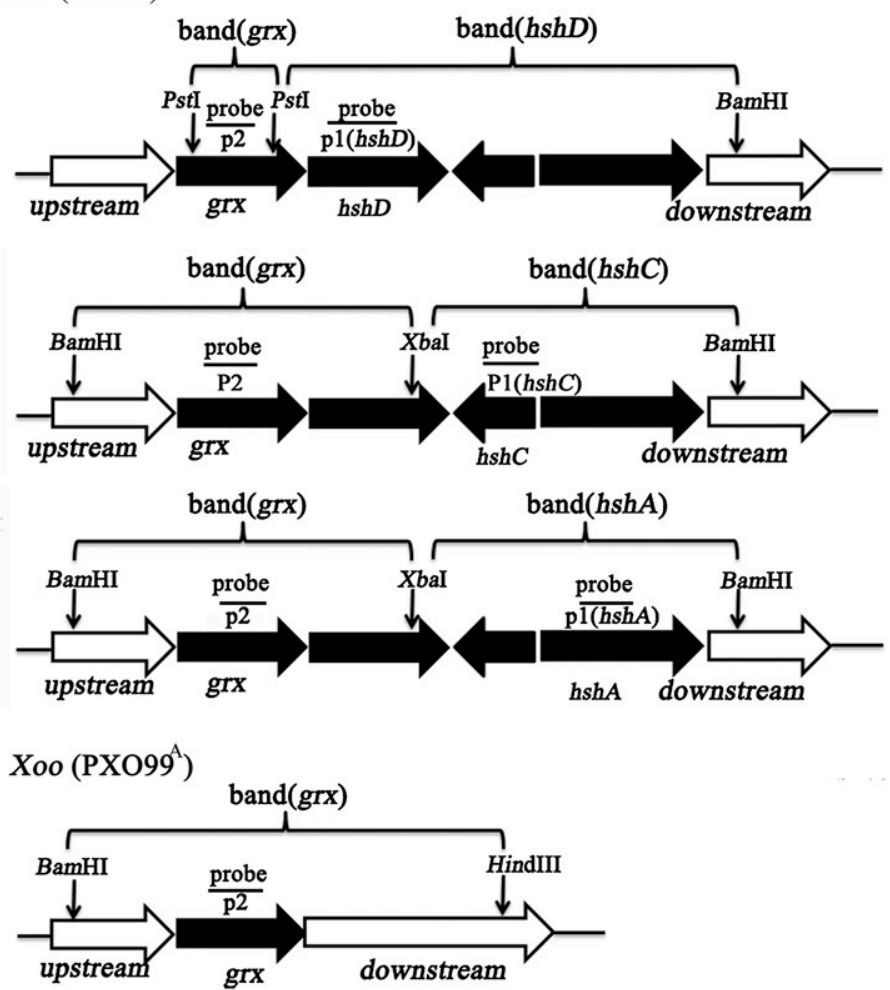

B

Probe: P1-hshD \& P2 P1-hshC \& P2 P1-hshA \& P2

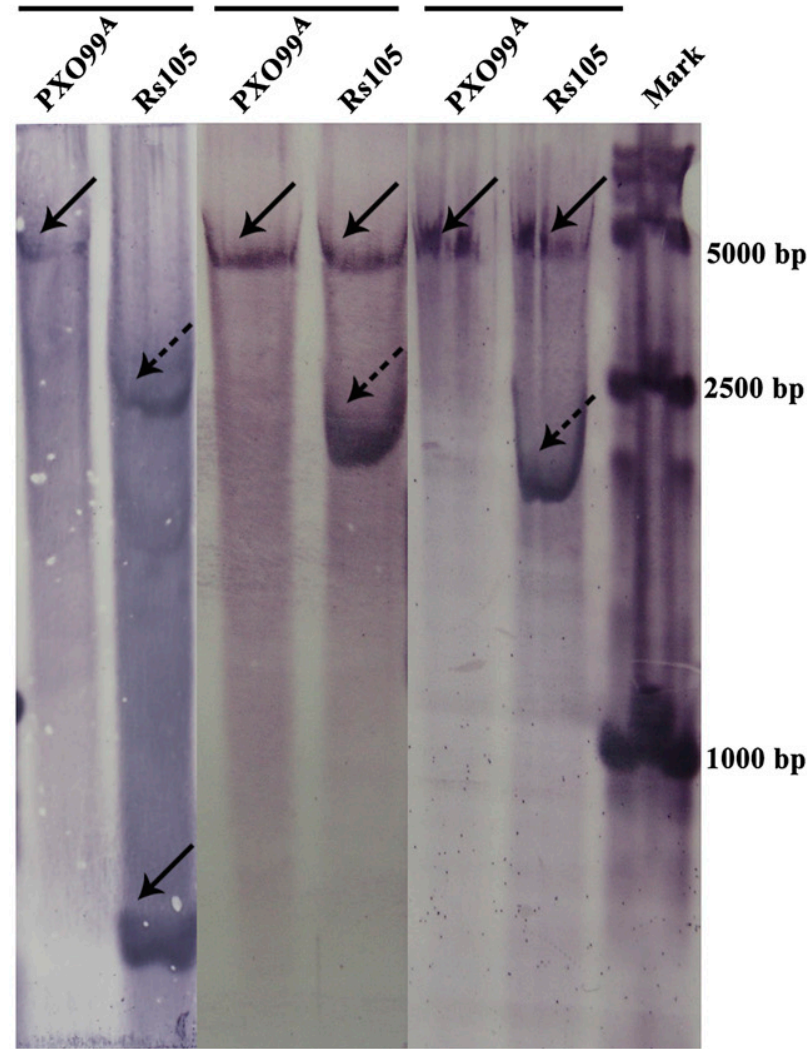

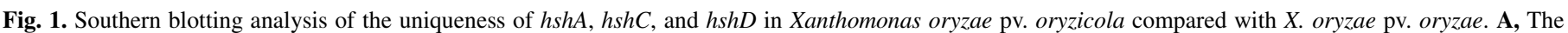

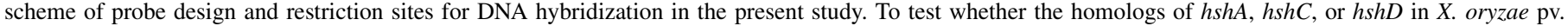

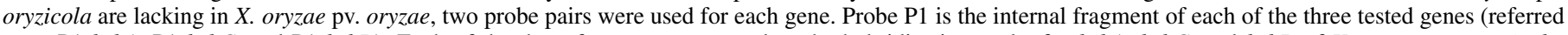
to as P1-hshA, P1-hshC, and P1-hshD). Each of the three fragments was used as the hybridization probe for $h s h A$, $h s h C$, and $h s h D$ of $X$. oryzae pv. oryzicola,

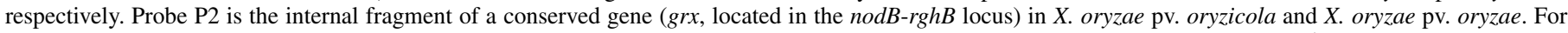
detection of each of the three target genes, the genomic DNA of strain Rs105 (wild-type X. oryzae pv. oryzicola) and strain PXO99A (wild-type X. oryzae pv.

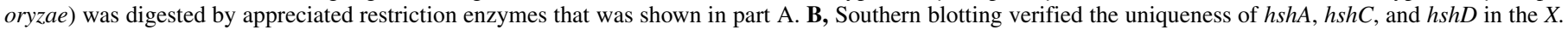

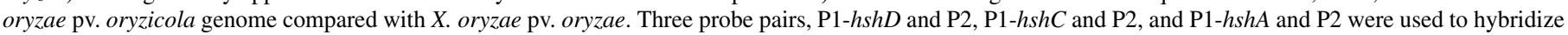

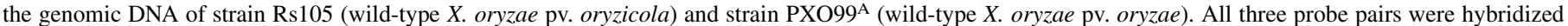

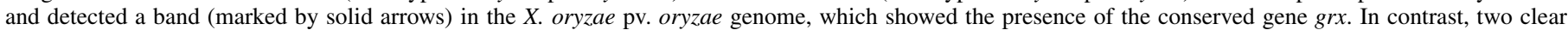

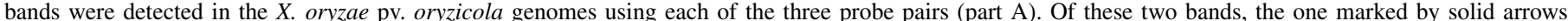

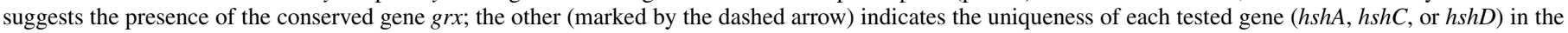
$X$. oryzae pv. oryzicola genome.

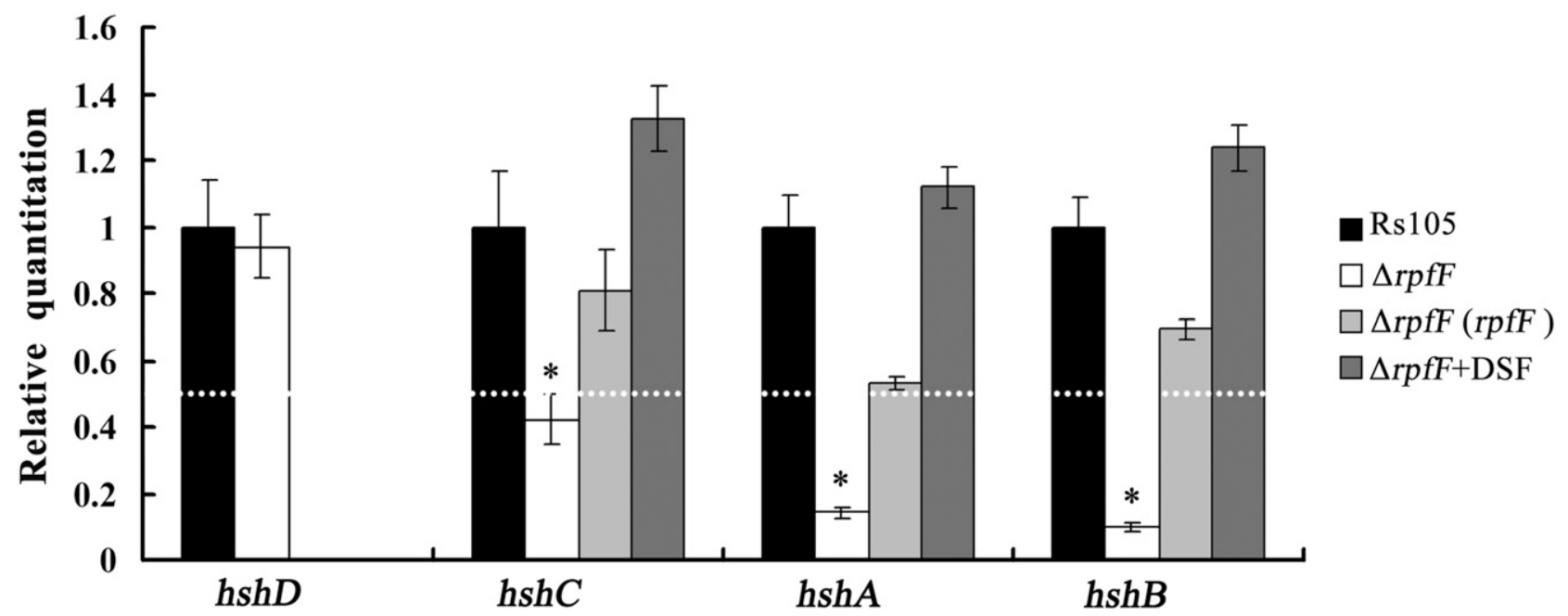

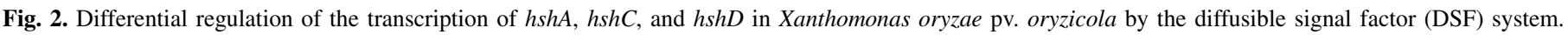

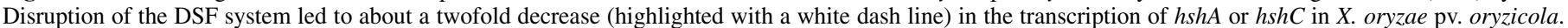

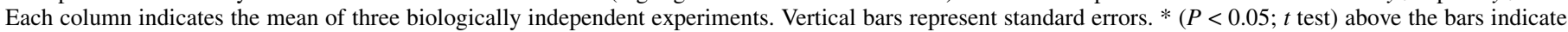

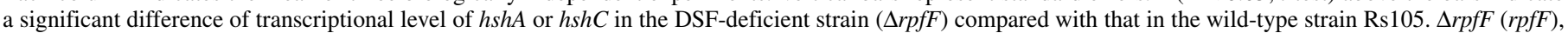

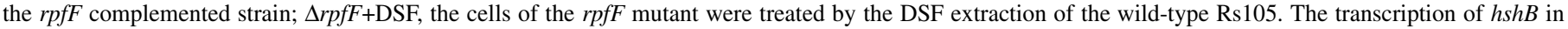
$\Delta r p f F$ was used as a positive control and found to be consistent with our previous results (26). 
evaluated based on the water-soaking lesion length. Surprisingly, two mutants $(\Delta h s h A$ and $\Delta h s h C)$ exhibited a significant reduction ( $\sim 2.0$-fold for $\Delta h s h A ; \sim 2.1$-fold for $\Delta h s h C$ ) in virulence when using the lowest $\left(\mathrm{OD}_{600 \mathrm{~nm}}=0.0005\right)$ of the tested concentrations, whereas their corresponding complemented strains retained wildtype ability in this function. Using the same method, we also tested the virulence of the double mutant $(\triangle h s h C A)$ (Supplementary Table 3), and found that in comparison with the wild-type Rs105, this double mutant only exhibited a significant reduction $(\sim 2.3$ fold) in virulence when using the low $\left(\mathrm{OD}_{600 \mathrm{~nm}}=0.0005\right)$, but not the relative high $(0.5,0.05$, or 0.005$)$ tested concentrations (Supplementary Fig. 4). Interestingly, at all cell concentrations used, the $h s h D$ deletion mutant did not exhibit altered virulence, indicating that this gene was not involved in the virulence of $X$. oryzae pv. oryzicola. Notably, in all experiments, the $h s h B$ mutant showed a consistent and remarkable decrease in virulence, in accordance with our previous findings (26). From the results of our DNA hybridization and pathogenicity tests (Figs. 1 and 3A), we concluded that $h s h A$ and $h s h C$, two genes in the nodB-rhgB locus of $X$. oryzae pv. oryzicola Rs 105 that were missing from $X$. oryzae $\mathrm{pv}$. oryzae PXO99A, were involved in $X$. oryzae pv. oryzicola virulence. Furthermore, these two genes ( $h s h A$ and $h s h C)$ probably did not have a cumulative contribution to the virulence of $X$. oryzae pv. oryzicola Rs105.

Next, to explore whether the involvement of $h s h A$ or $h s h C$ in virulence is related with the in planta colonization of the corresponding mutant, we detected the cell populations of these two mutants in the infected rice leaves. For this purpose, we used a low concentration $\left(\mathrm{OD}_{600 \mathrm{~nm}}=0.0005\right)$ of the wild-type Rs 105 and each mutant to inoculate rice leaves because in this way the role of the two genes in virulence could be visualized (Fig. 3A). We then recovered the bacterial cells from the infected rice leaves 10 days after inoculation. As shown in Figure 3B, the two mutants $(\Delta h s h A$ and $\Delta h s h C$ ) exhibited a remarkable decrease in cell numbers in comparison with the wild-type strain when recovered after 10 days. Under the same conditions, the corresponding complemented strain of $h s h A$ or $h s h C$ mutant exhibited wildtype level in this function, and the $h s h B$ mutant showed a significant decrease in cell populations, consistent with our previous findings (26). Taken together, these results suggested that mutation of $h s h A$ and $h s h C$ reduced the in planta growth ability of $X$. oryzae pv. oryzicola, which was one of the probable mechanisms underlying the involvement of these two genes in virulence.
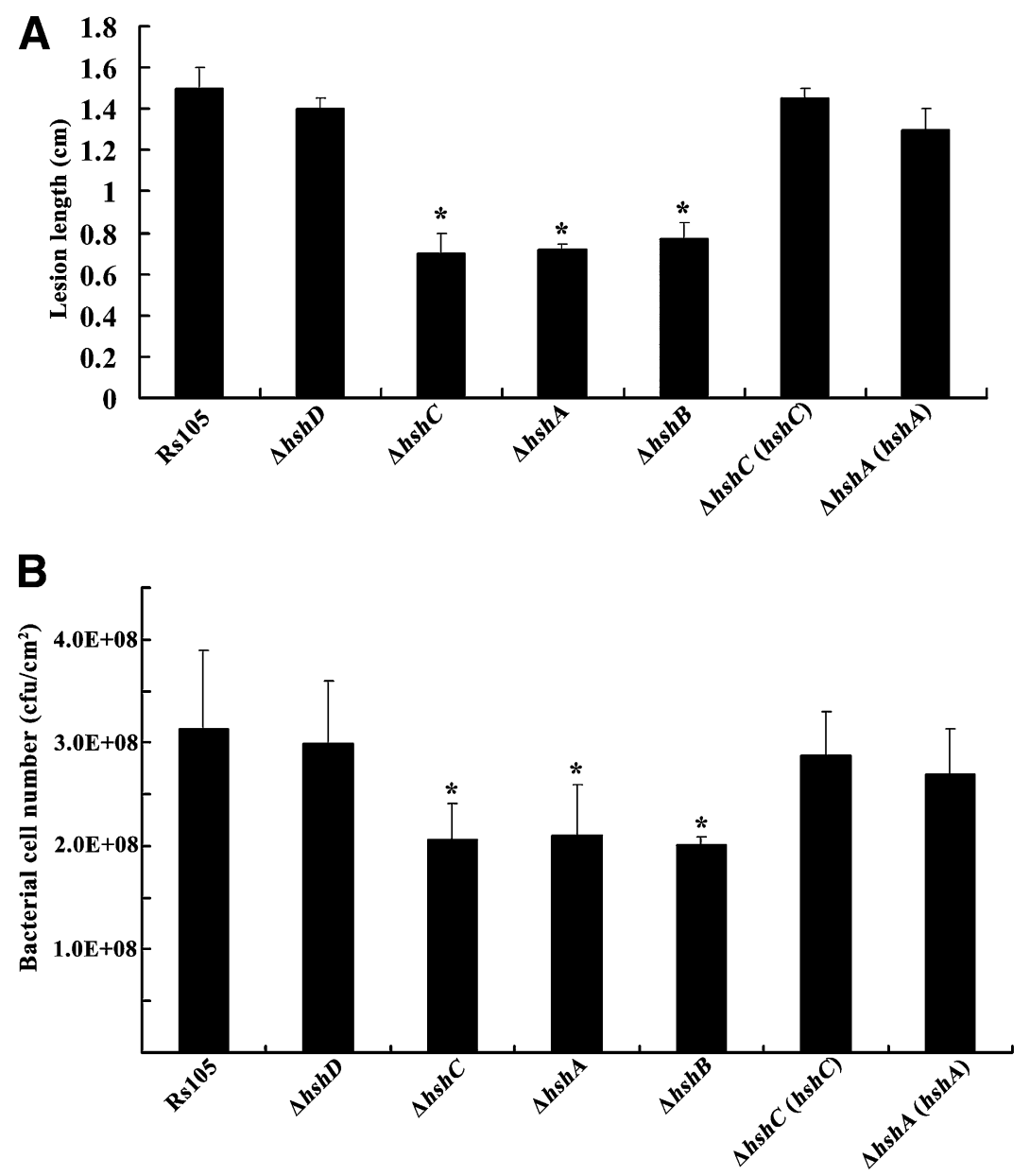

Fig. 3. Mutation of $h s h A$ and $h s h C$ reduced the virulence level and bacterial load on host rice using the low Xanthomonas oryzae pv. oryzicola inoculated cell density. A, Statistical analysis of the virulence of $X$. oryzae pv. oryzicola strains on host rice using a low $\left(\mathrm{OD}_{600 \mathrm{~nm}}=0.0005\right)$ inoculated cell density. B, In planta colonization ability of various $X$. oryzae pv. oryzicola strains in susceptible rice leaves. Bacteria were recovered from infected rice leaves (Shanyou-63) 10 days after inoculation using the low $\left(\mathrm{OD}_{600 \mathrm{~nm}}=0.0005\right)$ inoculated cell density. Each column indicates the mean of three biologically independent experiments. Vertical bars represent standard errors. $*(P<0.05 ; t$ test $)$ above the bars indicate a significant difference between mutant and the wild-type Rs 105 in tested phenotypes. Rs 105 , the wild-type strain of $X$. oryzae pv. oryzicola; $\Delta h s h D$, the $h s h D$ deletion mutant; $\Delta h s h C$, the $h s h C$ deletion mutant; $\Delta h s h A$, the $h s h A$ deletion mutant; $\Delta h s h C$ $(h s h C)$, the complemented strain of $\Delta h s h C ; \Delta h s h A(h s h A)$, the complemented strain of $\Delta h s h A$; and $\Delta h s h B$, the $h s h B$ deletion mutant, were used as a positive control (26). 
Both $h s h A$ and $h s h C$ are required for the epiphytic survival level of $X$. oryzae pv. oryzicola. Both $h s h A$ and $h s h C$ required for the full virulence in low density would lead to question whether they play an important role in the initial stages of inoculation. To test this point, we performed additional experiments to test whether the epiphytic survival in the early colonization stage is affected when $h s h A$ or $h s h C$ was mutated. As shown in Figure 4A, the $h s h A$ and $h s h C$ mutant exhibited a reduction on the cell populations recovered from the rice leaf surface at all the selected time points $(0.5,4,12,20$, and $28 \mathrm{~h})$ in comparison with the wildtype Rs105. Meanwhile, the complemented strain of $h s h A$ or $h s h C$ mutant restored to wild-type level in recovered cell populations. By using an AUPDC methodology, we found that the $h s h A$ or $h s h C$ mutant showed a significant reduction $(P<0.05 ; t$ test $)$ of epiphytic survival (cell numbers) in comparison with the wild-type strain during the total of 28-h colonization process (Fig. 4B). Furthermore, the complemented strain of $h s h A$ and $h s h C$ mutant retained wild-type level in this function. Collectively, these results suggest that $h s h A$ and $h s h C$ were probably involved in the epiphytic fitness of $X$. oryzae pv. oryzicola, which also probably contributed to the reduced virulence of the $h s h A$ and $h s h C$ mutant.

The involvement of $h s h A$ and $h s h C$ in virulence is not associated with the several characterized virulence-related traits in $X$. oryzae pv. oryzicola. Previously, we demonstrated the involvement of $h s h B$ in virulence, probably through impairing several important virulence-related traits, including EPS production and antioxidative activity (26). To test whether $h s h A$ and $h s h C$ could affect virulence-related traits and, in turn, modulate virulence, we compared the wild-type Rs105 and the $\Delta h s h A, \Delta h s h C$ or double mutant in terms of four well-studied virulence-associated functions, including in vitro growth, extracellular protease activity, resistance to oxidative stress, and EPS production. Unexpectedly, no visible alteration in the tested phenotypes/functions was detected between each single mutant or double mutant and the wild-type strain (Supplementary Figs. 5 to 9). These results indicate that the involvement of $h s h A$ and $h s h C$ in virulence was independent of our tested virulence-associated functions.

\section{DISCUSSION}

The present study indicates that the nodB-rhgB locus in $X$. oryzae pv. oryzicola Rs105 affected virulence. This locus displayed two interesting features in terms of its sequence and genomic organization. One is that the three genes $(\operatorname{nod} B, \operatorname{grx}$, and $\operatorname{rhg} B)$ at this locus were highly conserved in different Xanthomonas and related species (Table 1). However, their functions have not been described. The other is that the seven remaining genes exhibited diversity in terms of number; different Xanthomonas species utilizing different infection mechanisms may possess any number of homologs of these seven genes in $X$. oryzae pv. oryzicola. For instance, similar to $X$. oryzae $\mathrm{pv}$. oryzicola $\mathrm{Rs} 105, X$. axonopodis $\mathrm{pv}$. citri 306 , and $X$. campestris pv. vesicatoria $85-10$ are all mesophilic pathogens; three virulence-associated genes ( $h s h A, h s h B$, and $h s h C$ ) were all present in the $X$. campestris pv. vesicatoria 85-10 genome,
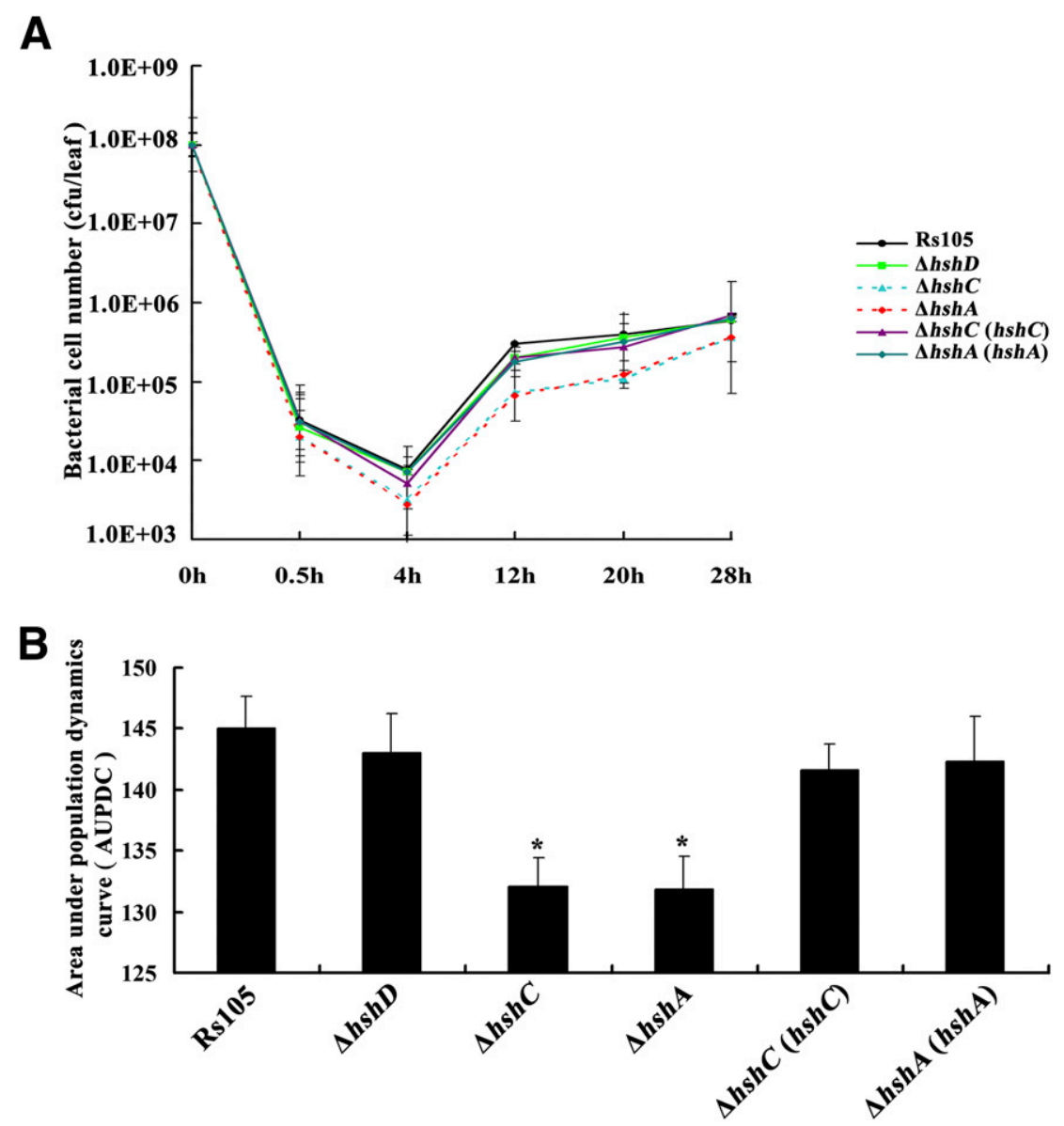

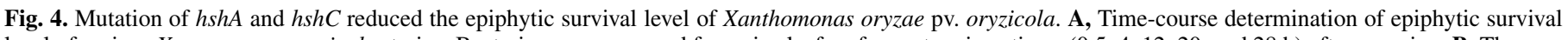

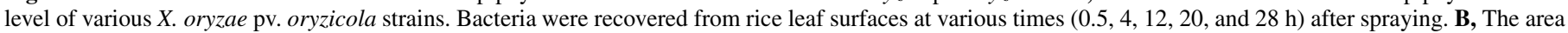

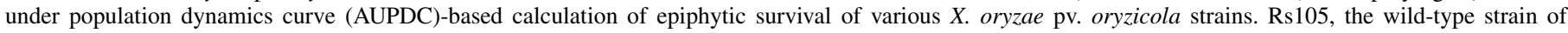

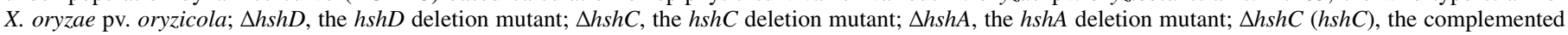

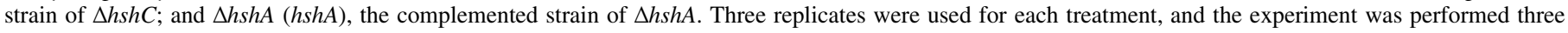

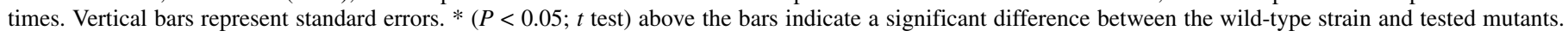


but only one ( $h s h C)$ was detected in the $X$. axonopodis pv. citri 306 genome. Interestingly, although $X$. campestris pv. campestris ATCC33913 is a vascular pathogen, it contains all of the homologs of these three virulence-related genes from $X$. oryzae pv. oryzicola Rs 105. More interestingly, three model $X$. oryzae pv. oryzae strains, X. oryzae pv. oryzae PXO99A, X. oryzae pv. oryzae MAFF311018, and $X$. oryzae pv. oryzae KACC10331 lacked all of these three genes, despite the fact that $X$. oryzae pv. oryzae and $X$. oryzae pv. oryzicola are highly similar in taxonomy and genome structure. Currently, the role of this locus in the above-noted Xanthomonas species has not been fully described. Elucidation of its role and mechanisms will provide useful information for understanding whether this locus or certain genes within this locus plays a conserved role in different Xanthomonas species.

Previously, we showed that $h s h A$ and $h s h B$ are cotranscribed (26). The gene $h s h B$ was previously shown to be controlled both by the DSF system (26). In the present study, we further showed that the patterns of transcriptional regulation of $h s h A$ and $h s h B$ by the DSF system are highly consistent; this finding was in accordance with our qRT-PCR results. Interestingly, although $h s h A$ and $h s h B$ are cotranscribed and share similar domains, they exhibit different functions. They were both involved in the bacterial colonization of rice tissues (Fig. 3B); however, $h s h B$ plays a critical and distinct role in extracellular protease activity, oxidative stress, and EPS production in $X$. oryzae pv. oryzicola; these functions were not found to be regulated by $h s h A$ (Supplementary Figs. 6 to 8). Our results indicate that the two cotranscribed and similar domaincontaining proteins (HshA and $\mathrm{HshB}$ ) at this locus contributed to the virulence of $X$. oryzae pv. oryzicola via shared and distinct mechanisms. In addition to $h s h A$, another interesting virulenceassociated gene within this locus is $h s h C$. In the $X$. oryzae pv. oryzicola genome, the predicted transcriptional direction of this gene was opposite to that of $h s h A$, indicating that this gene might not be cotranscribed with $h s h A$. Although $h s h C$ is annotated as a hypothetical protein of unknown function in $X$. oryzae pv. oryzicola, we however, found it was involved in the virulence and regulated by the DSF system in $X$. oryzae pv. oryzicola. Interestingly, although $h s h A$ and $h s h C$ were both involved in virulence, they, however, did not exhibit an accumulative effect on virulence. Addressing the precise molecular virulence mechanism used by $h s h A$ and $h s h C$ is deserved for further studies.

The DSF signaling pathway is a conserved system in Xanthomonas $(9,20)$. This system regulates virulence and virulenceassociated traits in diverse Xanthomonas species; however, the regulatory mechanism is different in some species. For example, the DSF system positively regulates motility and negatively modulates biofilm formation in $X$. campestris pv. campestris, but this mechanism is different in $X$. oryzae pv. oryzae (20). In this study and in our previous report, we found that three genes $(h s h A, h s h B$, and $h s h C$ ) within the $n o d B-r h g B$ locus were controlled by DSFs and that they were involved in virulence (Figs. 2 and 3) (26). Interestingly, homologs of these three genes were absent in X. oryzae pv. oryzae. This finding suggests that $X$. oryzae pv. oryzicola utilized a DSFcontrolled and $X$. oryzae pv. oryzae-independent means of regulating virulence. A systematic analysis of the effect of these three genes on gene/protein expression at the genome-wide level both in $X$. oryzae pv. oryzicola (wild-type versus mutant strains) and $X$. oryzae pv. oryzae (wild-type versus over-expression strains) will help us understand how they modulate virulence in $X$. oryzae. Although $X$. oryzae pv. oryzae lacks homologs of these three genes, $X$. campestris pv. campestris possesses them. This suggests that the homologs of these three genes are also controlled by DSF signaling and influence the virulence of $X$. campestris pv. campestris. However, a previous microarray study showed that not all of them were regulated at the transcriptional level by DSF signaling (12). This finding indicates that the transcriptional regulation of these three genes by the DSF system varies among Xanthomonas species. We currently do not know their functions in the virulence of
$X$. campestris pv. campestris; further elucidation of this function in $X$. campestris pv. campestris will expand our understanding of the DSF regulatory mechanisms in different species of Xanthomonas.

In summary, this study describes two novel DSF-controlled, virulence-related genes in the $\operatorname{nodB}-\operatorname{rhg} B$ locus of $X$. oryzae pv. oryzicola. These two genes ( $h s h A$ and $h s h C)$ were experimentally found to be unique in X. oryzae pv. oryzicola Rs105 compared with $X$. oryzae pv. oryzae PXO99A. The decrease of $h s h A$ or $h s h C$ in virulence was associated with the reduced in planta growth and epiphytic survival level of the $h s h A$ or $h s h C$ mutant in $X$. oryzae pv. oryzicola Rs105.

\section{ACKNOWLEDGMENTS}

This work was supported by the National Natural Science Foundation of China (31171810; 31371906) and Special Fund for Agro-Scientific Research in the Public Interest (No. 201303015; 201003021).

\section{LITERATURE CITED}

1. Barber, C. E., Tang, J. L., Feng, J. X., Pan, M. Q., Wilson, T. J. G., Slater, H., Dow, J. M., Williams, P., and Daniels, M. J. 1997. A novel regulatory system required for pathogenicity of Xanthomonas campestris is mediated by a small diffusible signal molecule. Mol. Microbiol. 24:555-566.

2. Bjarko, M. E., and Line, R. F. 1988. Heritability and number of genes controlling leaf rust resistance in four cultivars of wheat. Phytopathology 78:457-461.

3. Boon, C., Deng, Y., Wang, L. H., He, Y. W., Xu, J. L., Fan, Y., Pan, S. Q., and Zhang, L. H. 2008. A novel DSF-like signal from Burkholderia cenocepacia interferes with Candida albicans morphological transition. ISME J. 2:27-36.

4. Büttner, D., and Bonas, U. 2010. Regulation and secretion of Xanthomonas virulence factors. FEMS Microbiol. Rev. 34:107-133.

5. Chatterjee, S., Newman, K. L., and Lindow, S. E. 2008. Cell-to-cell signaling in Xylella fastidiosa suppresses movement and xylem vessel colonization in grape. Mol. Plant-Microbe Interact. 21:1309-1315.

6. Colnaghi Simionato, A. V., Da Silva, D. S., Lambais, M. R., and Carrilho, E. 2007. Characterization of a putative Xylella fastidiosa diffusible signal factor by HRGC-EI-MS. J. Mass Spectrom. 42:1375-1381.

7. De Feyter, R., Kado, C. I., and Gabriel, D. W. 1990. Small, stable shuttle vectors for use in Xanthomonas. Gene 88:65-72.

8. Deng, Y., Wu, J. E., Eberl, L., and Zhang, L. H. 2010. Structural and functional characterization of diffusible signal factor family quorumsensing signals produced by members of the Burkholderia cepacia complex. Appl. Environ. Microbiol. 76:4675-4683.

9. Deng, Y., Wu, J. E., Tao, F., and Zhang, L. H. 2011. Listening to a new language: DSF-based quorum sensing in gram-negative bacteria. Chem. Rev. 111:160-173.

10. Fouhy, Y., Scanlon, K., Schouest, K., Spillane, C., Crossman, L., Avison, M. B., Ryan, R. P., and Dow, J. M. 2007. Diffusible signal factordependent cell-cell signaling and virulence in the nosocomial pathogen Stenotrophomonas maltophilia. J. Bacteriol. 189:4964-4968.

11. Fuqua, C., and Greenberg, E. P. 2002. Listening in on bacteria: Acylhomoserine lactone signaling. Nat. Rev. Mol. Cell Biol. 3:685-695.

12. He, Y. W., Ng, A. Y., Xu, M., Lin, K., Wang, L. H., Dong, Y. H., and Zhang, L. H. 2007. Xanthomonas campestris cell-cell communication involves a putative nucleotide receptor protein Clp and a hierarchical signaling network. Mol. Microbiol. 64:281-292.

13. He, Y. W., Wang, C., Zhou, L., Song, H. W., Dow, J. M., and Zhang, L. H. 2006. Dual signaling functions of the hybrid sensor kinase RpfC of Xanthomonas campestris involve either phosphorelay or receiver domainprotein interaction. J. Biol. Chem. 281:33414-33421.

14. He, Y. W., Xu, M., Lin, K., Ng, Y. J., Wen, C. M., Wang, L. H., Liu, Z. D., Zhang, H. B., Dong, Y. H., Dow, J. M., and Zhang, L. H. 2006. Genome scale analysis of diffusible signal factor regulon in Xanthomonas campestris pv. campestris: Identification of novel cell-cell communicationdependent genes and functions. Mol. Microbiol. 59:610-622.

15. Mole, B. M., Baltrus, D. A., Dangl, J. L., and Grant, S. R. 2007. Global virulence regulation networks in phytopathogenic bacteria. Trends Microbiol. 15:363-371.

16. Newman, K. L., Almeida, R. P. P., Purcell, A. H., and Lindow, S. E. 2004. Cell-cell signaling controls Xylella fastidiosa interactions with both insects and plants. Proc. Natl. Acad. Sci. USA 101:1737-1742.

17. Qian, G. L., Liu, C. H., Wu, G. C., Yin, F. Q., Zhao, Y. C., Zhou, Y. J., Zhang, Y. B., Song, Z. W., Fan, J. Q., Hu, B. S., and Liu, F. Q. 2013. AsnB, regulated by diffusible signal factor and global regulator $\mathrm{Clp}$, is 
involved in aspartate metabolism, resistance to oxidative stress, and virulence in Xanthomonas oryzae pv. oryzicola. Mol. Plant Pathol. 14:145-157.

18. Qian, G. L., Zhang, Y. B., Zhou, Y. J., Liu, C. H., Zhao, Y. C., Song, Z. W., Fan, J. Q., Hu, B. S., and Liu, F. Q. 2012. epv, encoding a hypothetical protein, is regulated by DSF-mediating quorum sensing as well as global regulator Clp and is required for optimal virulence in Xanthomonas oryzae pv. oryzicola. Phytopathology 102:841-847.

19. Qian, G. L., Zhou, Y. J., Zhao, Y. C., Song, Z. W., Wang, S. Y., Fan, J. Q., Hu, B. S., Venturi, V., and Liu, F. Q. 2013. Proteomic analysis reveals novel extracellular virulence-associated proteins and functions regulated by the diffusible signal factor (DSF) in Xanthomonas oryzae pv. oryzicola. J. Proteome Res. 12:3327-3341.

20. Rai, R., Ranjan, M., Pradhan, B. B., and Chatterjee, S. 2012. Atypical regulation of virulence-associated functions by a diffusible signal factor in Xanthomonas oryzae pv. oryzae. Mol. Plant-Microbe Interact. 25:789-801.

21. Ryan, R. P., Fouhy, Y., Lucey, J. F., Crossman, L. C., Spiro, S., He, Y. W., Zhang, L. H., Heeb, S., Cámara, M., Williams, P., and Dow, J. M. 2006. Cell-cell signaling in Xanthomonas campestris involves an HD-GYP domain protein that functions in cyclic di-GMP turnover. Proc. Natl. Acad. Sci. USA 103:6712-6717.

22. Ryan, R. P., Vorhölter, F. J., Potnis, N., Jones, J. B., Van Sluys, M. A., Bogdanove, A. J., and Dow, J. M. 2011. Pathogenomics of Xanthomonas understanding bacterium-plant interactions. Nat. Rev. Microbiol. 9:344-355.
23. Tang, J. L., Liu, Y. N., Barber, C. E., Dow, J. M., Wootton, J. C., and Daniels, M. J. 1991. Genetic and molecular analysis of a cluster of rpf genes involved in positive regulation of synthesis of extracellular enzymes and polysaccharide in Xanthomonas campestris pathovar campestris. Mol. Gen. Genet. 226:409-417.

24. Wang, L. H., He, Y. W., Gao, Y. F., Wu, J. E., Dong, Y. H., He, C. Z., Wang, S. X., Weng, L. X., Xu, J. L., Tay, L., Fang, R. X., and Zhang, L. H. 2004. A bacterial cell-cell communication signal with cross-kingdom structural analogues. Mol. Microbiol. 51:903-912.

25. Watt, S. A., Wilke, A., Patschkowski, T., and Niehaus, K. 2005. Comprehensive analysis of the extracellular proteins from Xanthomonas campestris pv. campestris B100. Proteomics 5:153-167.

26. Zhao, Y. C., Qian, G. L., Fan, J. Q., Liu, C. H., Yin, F. Q., Zhou, Y. J., Shen, Q., Hu, B. S., and Liu, F. Q. 2012. Identification and characterization of a novel gene $h s h B$ in Xanthomonas oryzae pv. oryzicola coregulated by quorum sensing and clp. Phytopathology 102:252-259.

27. Zhao, Y. C., Qian, G. L., Yin, F. Q., Fan, J. Q., Zhai, Z. W., Liu, C. H., Hu, B. S., and Liu, F. Q. 2011. Proteomic analysis of the regulatory function of DSF-dependent quorum sensing in Xanthomonas oryzae pv. oryzicola. Microbiol. Pathog. 50:48-55.

28. Zou, L. F., Li, Y. R., and Chen, G. Y. 2011. A non-marker mutagenesis strategy to generate poly-hrp gene mutants in the rice pathogen Xanthomonas oryzae pv. oryzicola. Agric. Sci. China 10:1139-1150. 